\title{
Problematic Student Identification and Visualization in The Counseling Activites
}

\author{
Evaliata Br Sembiring ${ }^{1}$, Bery Febriyanto. ${ }^{2}$ \\ 1,2 Informatics Engineering Department of Politeknik Negeri Batam, Batam Center, Indonesia
}

\begin{abstract}
The counseling activities are procedures carried out by academic advisers to identify problematic students, especially in their academic learning process. Students are categorized as problematic when they do not submit their KRS, have a lower GPA than the college standard, have not yet paid their due, or receive warning letters owing to their misconducts. The current system provides every students' data but academic advisers still need to identify every problematic students' data one by one. A working solution would be to present the data in a visualization, so the problematic students along with their problem category can be identified automatically. The application employs the UML approach in its planning and web-based application development tools in its implementation. Highchart is implemented in the data visualization. The resulted application boasts the student data management feature to help the problematic student identification process. This feature automatically identifies the problematic students on each term by visualizing it in a colored charts and tables.
\end{abstract}

Index Terms-Identification, Visualization, College students, Counseling.

\section{Introduction}

The counseling activities administered in Politeknik Negeri Batam are carried out to assure that the students can readily conduct all of their academic activities. This is one of the methods to help students to finish their education on schedule. Many problems can cause students unable to complete their current academic activities. These problems can be either academic or non-academic. These problematic students should be identified immediately — by the lecturer designated as their academic adviser- to quickly overcome the problem, ensuring the continuity of their subsequent academic activities.

The problematic students can be grouped into three categories: (1) those who have not yet paid their duetherefore unable to fill in their KRS (Kartu Rencana Studi, study plan application form), (2) those who have low cumulative grade point average below the college standard - thus, unable to complete their education on time, (3) those with warning letters - caused either by absence, campus regulations violation, or any other reasons.

SIA (Sistem Informasi Akademik, academic information system) has provided every students' data such as their grades and some additional notes about them in the format of forms filled by their adviser. However, this still leaves a problem since advisers still need to check every problematic students' data one by one, which is tedious and timeconsuming, and usually leads to the adviser abandoning the routine altogether and only do it when a problem arise, forcing the problematic student to see their adviser-either to fill in their KRS, to retake previous subjects they have not passed yet, to deal with their warning letters, etc. Moreover, these problems usually emerge after a deadline has passed, so these students must wait for a long time - or even take one semester break - until they are allowed to resume their study. This can be solved by early identification of the problematic students, which facilitates early solution.

To help decision-making, data can be displayed using visualization. This technique is known for its ability transform textual data into their visual or symbolic form, therefore speeding up the data's pattern, tendency, and meaning recognition process [5]. Visualization can enhance its user's cognition because of its capability to shape interactive visual data [6]. Data need to be visualized, so the information can be communicated clearly and efficiently, easily accessed, and used in a logic or analysis [2].

Some previous applications of data or information visualization on different purposes include: information exploration process enhancement using reference machine [1]; data searching [2]; financial report analysis [3]; and responsibility report presentation [4].

It is possible to implement this visualization technique in the development of the problematic student identification system. The visualization utilizes chart and color, by applying Highchart.

\section{System Description}


The developed identification system resembles the current conventional system, as shown in Figure 1.

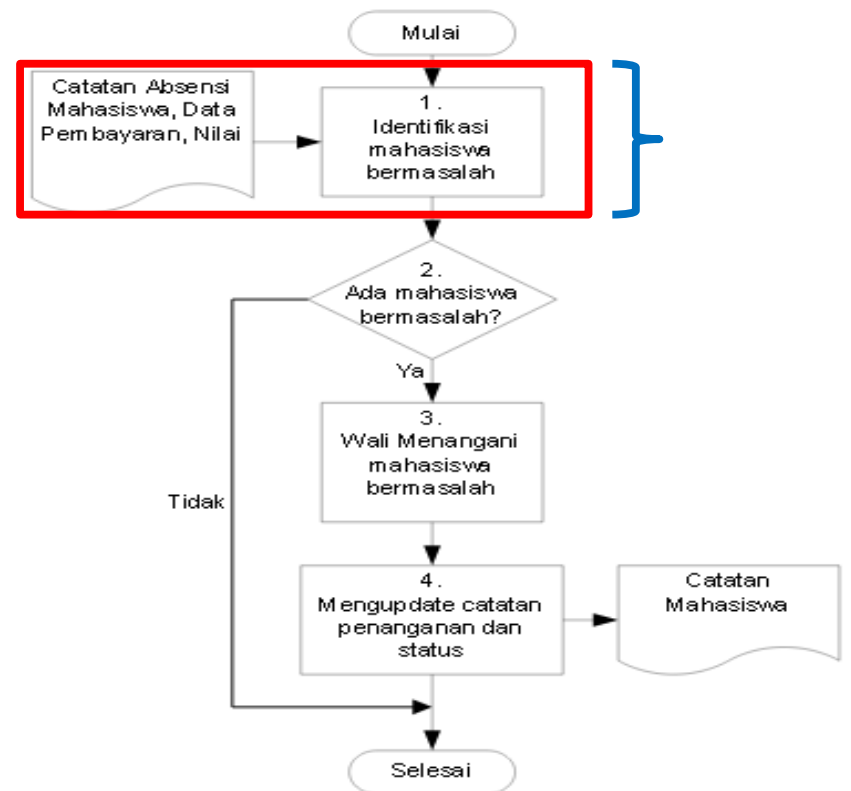

Fig. 1. Problematic Student Identification Procedure (source: http://intranet.polibatam.ac.id/)

There are two user categories, Administrator and PA (Pembimbing Akademik, academic adviser), illustrated in Figure 2. The Administrator has the authority to access and manage the data required for the problematic student identification process. These data consist of the data of all students, academic advisers, students' problems and their categories. Academic advisers will identify problematic students based on the data visualization. They can also view the problematic student data recapitulation on each term.

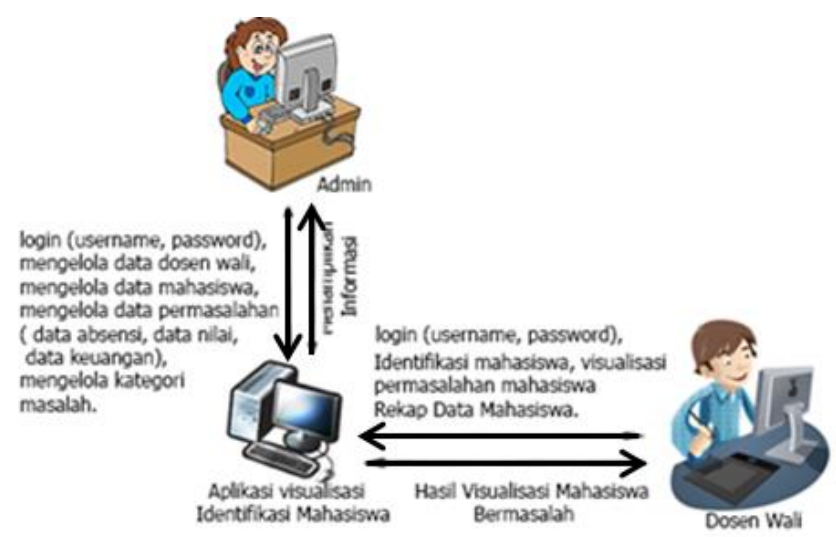

Fig. 2. Description of The Problematic Student Identification and Visualization Application

The functional requirements for the application's development include the management of data and user's access and the presentation of data - in colored charts - as well as the recapitulation.

These can be further decomposed into 16 functional requirements as shown in the use case diagram in Figure 3.

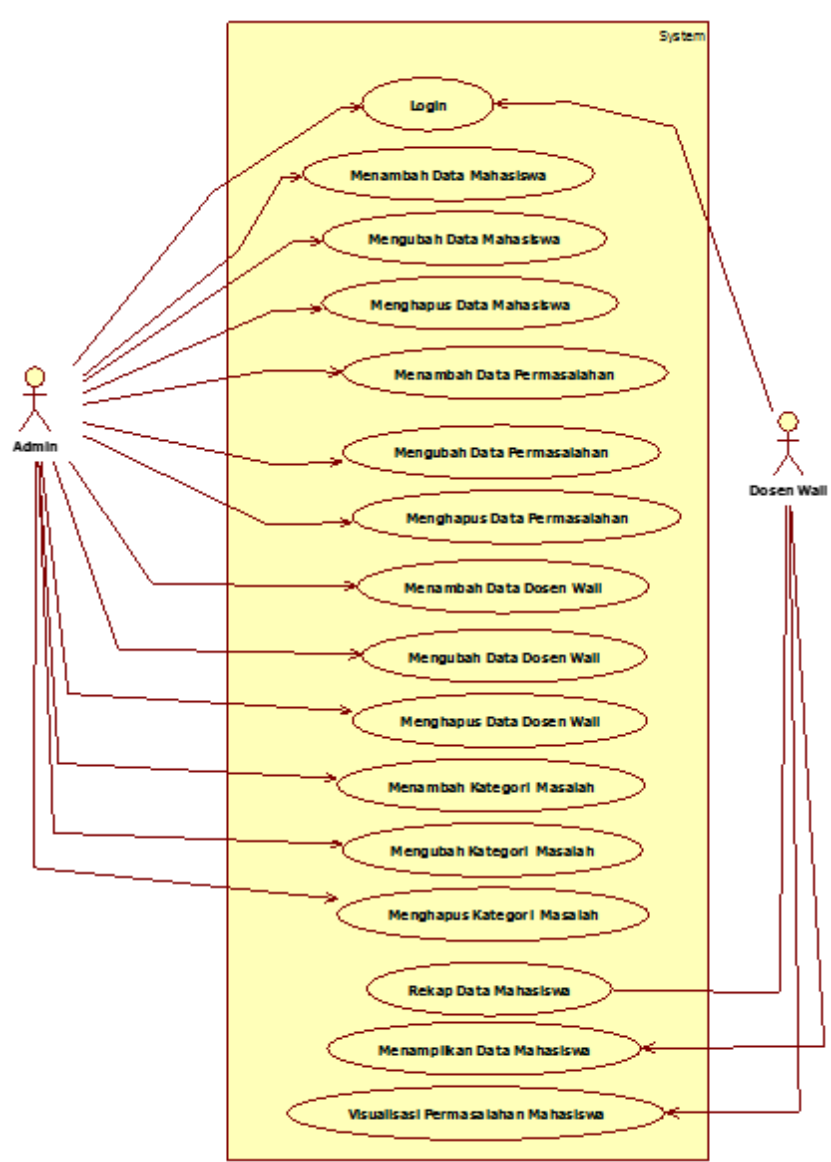

Fig. 3. The Use-Case Diagram of Problematic Student Identification and Visualization Application

Since the UML (Unifield Modeling Language) model is employed as the method, the use case scenario (Table 1), activity diagram (Figure 4), sequence diagram (Figure 5), and class diagram can also be determined from the use case diagram above.

Table 1

Problematic Student Visualization Scenario

\begin{tabular}{|c|c|}
\hline Use case name & Student's Problem Visualization \\
\hline Description & $\begin{array}{l}\text { Academic Adviser views the student's problem } \\
\text { visualization }\end{array}$ \\
\hline Actor & Academic Adviser \\
\hline Start Condition & Academic Adviser accesses the student data GUI \\
\hline End Condition & $\begin{array}{l}\text { The visualization is successfully displayed on a } \\
\text { table and chart }\end{array}$ \\
\hline \multirow[t]{4}{*}{ Scenario } & $\begin{array}{l}\text { 1. Academic Adviser moves the cursor to a } \\
\text { student's name }\end{array}$ \\
\hline & 2. The system displays the problem category \\
\hline & $\begin{array}{l}\text { 3. Academic Adviser chooses the problematic } \\
\text { student(s) }\end{array}$ \\
\hline & 4. The system shows the visualization \\
\hline
\end{tabular}




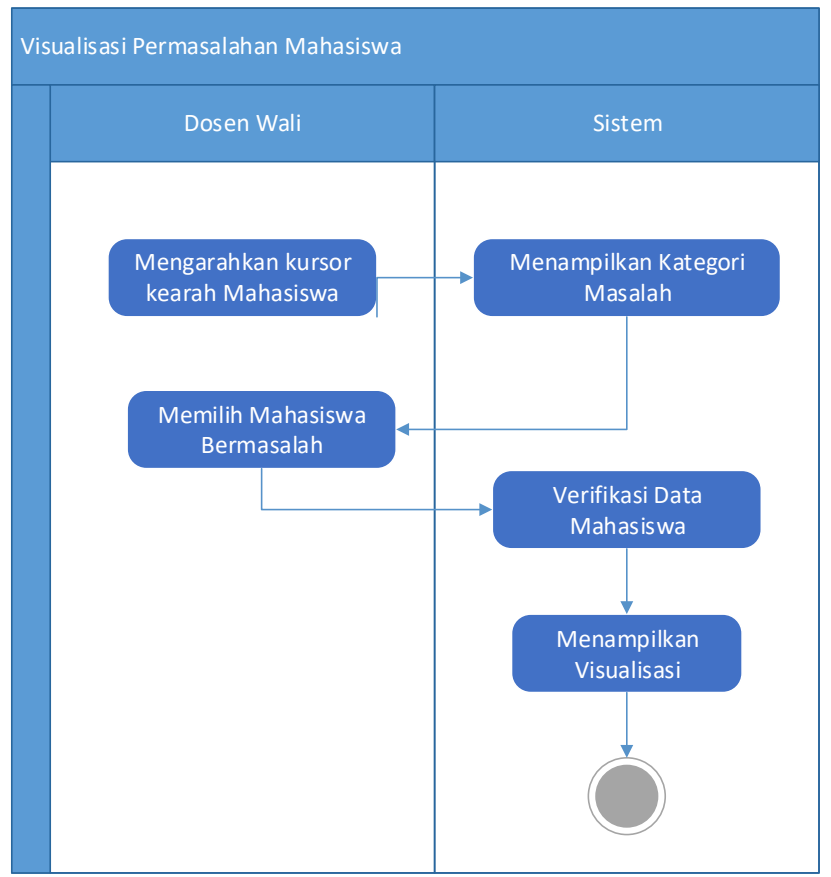

Fig. 4. The Activity Diagram of Problematic Student Identification and Visualization Application

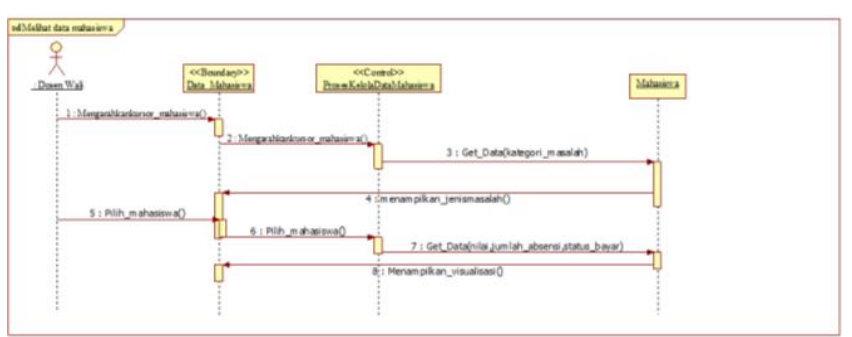

Fig.5. The Sequence Diagram of Problematic Student Identification and Visualization Application

The next step would be to design a database in form of an ERD (entity relationship diagram) and user interface (prototype).

\section{Results and Discussions}

The implementation of the resulted design made use of several programming language software, including HTML, PHP, Javascript (jQuery), and MySQL for the database. Highchartjs library was used in the implementation of the visualization. The realization of the Highchartjs implementation is shown in the source code in Figure 6.

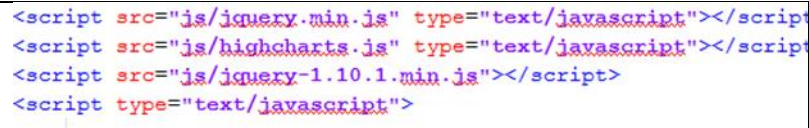

Fig.6. The Problematic Student Identification Highcartjs Implementation Source Code
The implementation of the 16 functional requirements and the database and interface design was then tested using the blackbox method (Table 2). All of them were successfully implemented and the interface also performed as planned.

1. All of the 16 planned functional requirementsconsisted of the requirements below-were successfully implemented.

a. On the administrator's side, there are 12 functional requirements: managing student data (adding, editing, and deleting student data), managing academic adviser data (adding, editing, and deleting academic adviser data), managing students' problem data (adding, editing, and deleting students' problem data), and managing problem category data (adding, editing, and deleting problem category data).

b. The process of inputting student data and commissioning academic adviser was carried out one by one, which was inefficient for data with a large amount. This research found that this can be rectified by integrating these data with the previous data from SIA, for example by uploading them.

c. On the academic adviser's side, there are 4 functional requirements: logging in, viewing student data, viewing problematic student data visualization, and recapitulating student data.

d. Every student's problem could be visualized in a chart. However, it is important to filter the display based on their academic adviser.

2. The system could manage the student datadepending on the user-according to their problem category by employing functions.

a. Administrator could input student data as well as commission their academic adviser.

b. Administrator could add the problem category, which could be color coded and displayed in a table later.

c. Academic adviser could filter the problematic student data based on the term and problem category.

d. Academic adviser could view the problematic student data recapitulation from the first until the current term. 
The Problematic Student Identification and Visualization Application Test Result

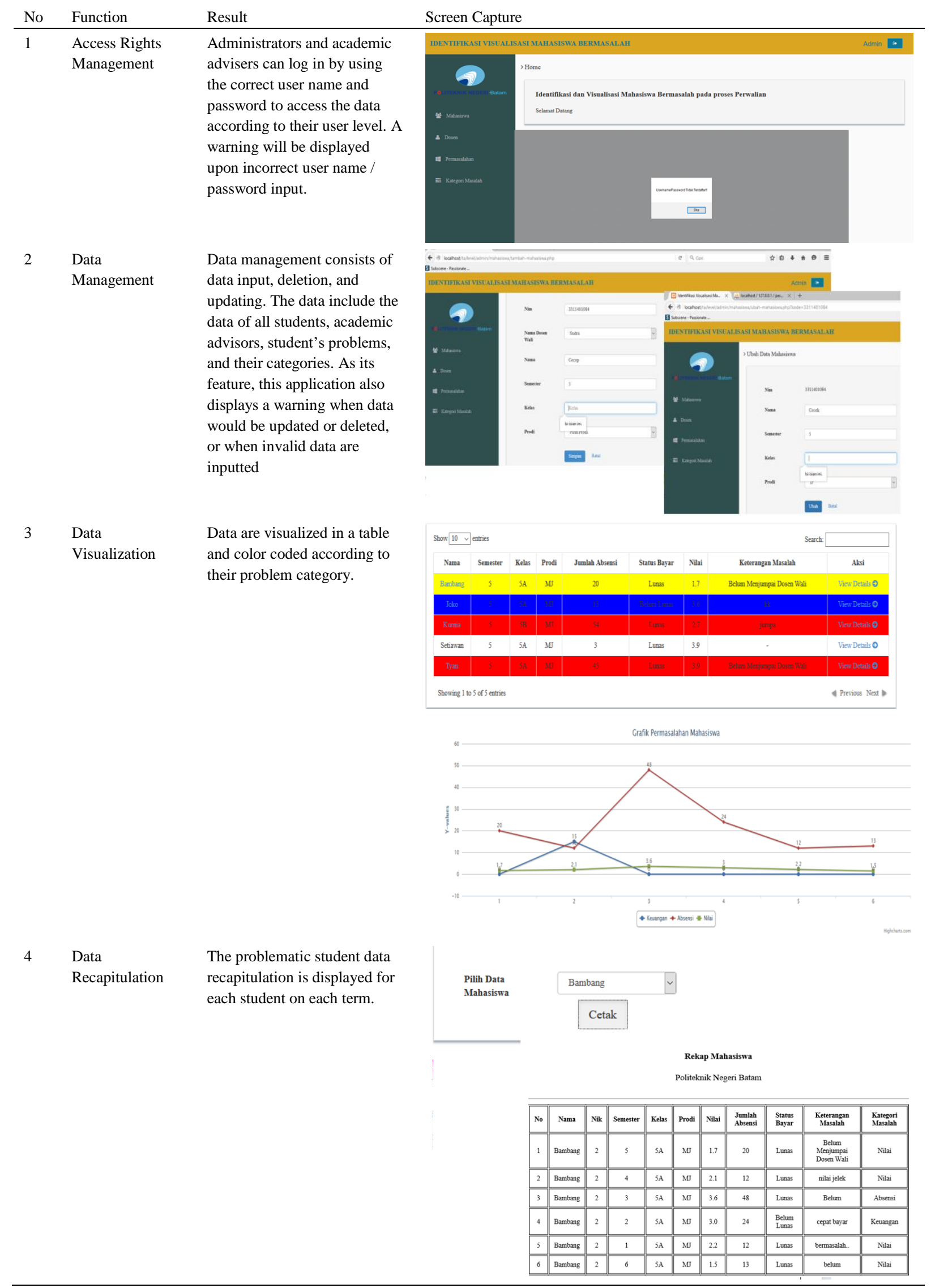


Based on the implementation, academic advisers could identify the problematic students-grouped into three problem categories (grade, attendance, payment status). This will be visualized through color coding: yellow for grade, red for attendance, and blue for payment status. In addition, academic advisers could view problematic students for each student on each term-visualized in a chart. The technology implemented for the visualization was the Higchart library.

\section{Conclusion}

1) The problematic student identification and visualization application was successfully developed by implementing the design based on 16 functional requirements. There are two user categories for the application with different access rights, depending on how they $\log$ in to the application. As the data input utilizes the input form system, an additional feature is needed to integrate data updates to SIA.

2) The application facilitates academic advisers to view the problematic student data-visualized as Highchart colored charts. The visualization is color codedbased on the student's problem category-into three categories: GPA, attendance, and tuition fee payment status; grade is coded as yellow, attendance red, and the payment status blue. The problematic student data charts visualize the data for each student on each term.

\section{References}

[1] M. K. Mufida, E.B. Sembiring, M. C. Kirana, F. Setiawan, Reference Engine Visualisasi Topik Tugas Akhir Mahasiswa Jurusan Teknik Informatika Politeknik Negeri Batam, Proceedings of $5^{\text {th }}$ Applied Business and Engineering Conference, Politeknik Manufaktur Negeri Bangka Belitung, Indonesia, 2017, p.48.

[2] I.A. Siswanto, Asmunin,APlikasi Visualisasi Data Mahasiswa dan Dosen dengan Memanfaatkan Highchart, Jurnal Manajemen Informasi, UNESA, Surabaya, Indonesia, 2016, Vo.5. [online: http://jurnalmahasiswa.unesa.ac.id/index.php/jurnal-manajemeninformatika/article/view/16356/20345 ]

[3] A.A. Khalil, A.Reza, B. Kanigoro, Pengembangan Aplikasi Visualisasi Data untuk Analisa Laporan Keuangan Perusahaan Terbuka Berbasis Web, Binus University, Jakarta, 2015.

[4] F.A.Muqtadiroh, Sholiq, S. A. Prabowo, Web Informasi Eksekutif pada Pemerintah Kabupaten Sidoarjo untuk Memonitor Laporan Pertanggungjawaban dalam Bentuk Visualisasi Grafik yang Dikembangkan dengan Metode Extreme Programming dan Standar Dokumen Readyset, Jurnal Sistem Informasi, ITS, Surabaya, Indonesia, 2014, Vol.5. [online: http://si.its.ac.id/data/sisfo_data/files/4_vol5no2.pdf ]

[5] C. Brock, P. Cairns. Beyond guidelines: what can we learn from the visual information seeking mantra?. Ninth International Conference on Information Visualisation (IV'05). IEEE, 2005.

[6] Shneiderman, Ben. "The eyes have it: A task by data type taxonomy for information visualizations." Visual Languages, Proceedings., IEEE Symposium on. IEEE, 1996. 